\title{
OPEN
}

\section{Author Correction: Comparative mode of action of the antimicrobial peptide melimine and its derivative Mel4 against Pseudomonas aeruginosa}

\author{
Muhammad Yasir, Debarun Dutta \& Mark D. P. Willcox \\ Correction to: Scientific Reports https://doi.org/10.1038/s41598-019-42440-2, published online 08 May 2019 \\ This Article contains a typographical error in the Results section under subheading "Interaction with \\ Lipopolysaccharides" where, \\ "The LAL test was used to assess the ability of the AMPs to interact and neutralize the LPS. Both melimine and \\ Mel4 inhibited LPS's ability to stimulate amoebocyte lysate in a dose-dependent manner as demonstrated in Table \\ $3 . "$ \\ should read: \\ "The LAL test was used to assess the ability of the AMPs to interact and neutralize the LPS. Both melimine and \\ Mel4 inhibited LPS's ability to stimulate amoebocyte lysate in a dose-dependent manner as demonstrated in Table \\ 2."
}

(i) Open Access This article is licensed under a Creative Commons Attribution 4.0 International License, which permits use, sharing, adaptation, distribution and reproduction in any medium or format, as long as you give appropriate credit to the original author(s) and the source, provide a link to the Creative Commons license, and indicate if changes were made. The images or other third party material in this article are included in the article's Creative Commons license, unless indicated otherwise in a credit line to the material. If material is not included in the article's Creative Commons license and your intended use is not permitted by statutory regulation or exceeds the permitted use, you will need to obtain permission directly from the copyright holder. To view a copy of this license, visit http://creativecommons.org/licenses/by/4.0/.

(c) The Author(s) 2019 